\title{
EXPERIENCE IN EMPLOYMENT RESETTLEMENT FOR ETHNIC MINORITIES DUE TO HYDROPOWER CONSTRUCTION IN SOME SOUTHEAST ASIAN COUNTRIES
}

\section{Nguyen Phung Quan}

Committee for Ethnic Minority Affairs

\begin{tabular}{|c|c|c|}
\hline \multicolumn{2}{|c|}{ ARTICLE INFO } & ABSTRACT \\
\hline Received: & 25/12/2019 & The construction and development of hydropower plant play an \\
\hline Revised: & $21 / 5 / 2020$ & $\begin{array}{l}\text { important and significant role in socio-economic, defense, and security } \\
\text { system of each country. From the plan to actual operation, the }\end{array}$ \\
\hline Published: & $10 / 6 / 2020$ & resettlement of communities who affected strongly by the hydropower \\
\hline & & nstruction has remained unsolved. One reason of this situation \\
\hline \multicolumn{2}{|l|}{ KEYWORDS } & is that employment policies for ethnic minorities who affected by \\
\hline \multicolumn{2}{|c|}{ Management science } & Vietnam as well as in other countries. Most of the key hydropower \\
\hline \multicolumn{2}{|c|}{ Employment policies } & construction sites are home to ethnic minority communities who are the \\
\hline \multicolumn{2}{|c|}{ Ethnic minorities policies } & most vulnerable but are directly affected by the relocation process. By \\
\hline \multicolumn{2}{|c|}{ Resettlement policies } & $\begin{array}{l}\text { empirical research methods, summarizing the experience of Laos, } \\
\text { Myanmar, Thailand and Cambodia which are located in the Southeast }\end{array}$ \\
\hline \multicolumn{2}{|l|}{ Ethnic minorities } & $\begin{array}{l}\text { Asian continent and have the same hydroelectricity development } \\
\text { potential to Vietnam, the study draws lessons in formulating and } \\
\text { completing job creation policies for ethnic minorities who are affected } \\
\text { hydropower construction in Vietnam. }\end{array}$ \\
\hline
\end{tabular}

\section{KINH NGHIỆM GIẢI QUYẾT VIỆC LÀM ĐỐI VỚI ĐỒNG BÀO DÂN TộC THIỂU SỐ TÁI ĐỊNH ĊỦ DO XÂY DỰNG THỦY ĐIỆN Ở MộT SỐ QUỐC GIA KHU VỰC ĐÔNG NAM Ả \\ Nguyễn Phùng Quân \\ Ủy ban Dân tộc}

\begin{tabular}{|c|c|c|}
\hline \multicolumn{2}{|c|}{ THÔNG TIN BÀI BÁO } & \multirow{3}{*}{$\begin{array}{l}\text { TÓM TÁ̛T } \\
\text { Việc xây dựng, phát triển thủy điện luôn có tầm quan trợng và ý nghĩa } \\
\text { đặc biệt về kinh tế - xã hội, quốc phòng, an ninh của mồi quốc gia. Từ } \\
\text { khi bắt đầu triển khai lập kế hoạch tới khi nhà máy được đưa vào vận }\end{array}$} \\
\hline Ngày nhận bài: & 25/12/2019 & \\
\hline Ngày hoàn thiện: & 2 & \\
\hline Ngày đăng: & $10 / 6 / 2020$ & hành, vấn đề tái định cư cho người dân bị ảnh hưởng do xây dựng thủy \\
\hline & & \\
\hline \multicolumn{2}{|l|}{ TÙ'KHÓA } & \\
\hline \multicolumn{2}{|l|}{ Khoa học quản lý } & trong nước cũng như nước ngoài. Hầu hết các khu vực xây dựng thủy \\
\hline \multicolumn{2}{|l|}{ Chính sách việc làm } & điện trọng điểm là nơi cư trú chủ yếu của đồng bào dân tộc thiểu số, đó \\
\hline \multicolumn{2}{|c|}{ Chính sách dân tộc thiểu số } & là nhóm người dễ bị tổn thương nhất nhưng lại là những người chịu ảnh \\
\hline \multirow{2}{*}{\multicolumn{2}{|c|}{$\begin{array}{l}\text { Chính sách tái định cư } \\
\text { Đồng bào dân tộc thiểu số }\end{array}$}} & ó trình tói đinb or Giỏi \\
\hline & & bình thường và phát triển cuôc sống cũng như an ninh, xã hôi, kinh tế \\
\hline & & $\begin{array}{l}\text { vùng đồng bào cư trú. Bằng phương pháp nghiên cứu thực tiền, phân tích } \\
\text { tồng kết kinh nghiệm của Lào, Myanmar, Thái Lan và Campuchia, các } \\
\text { quốc gia thuốc nhóm Đông Nam Á lục địa có cùng tiềm năng phát triển } \\
\text { thủy điện giống Việt Nam, nghiên cứu đưa ra bài học để xây dựng, hoàn } \\
\text { chỉnh chính sách giải quết việc làm đối với đồng bào dân tộc thiểu số } \\
\text { tái định cư do xây dưng thủy điện ở Việt Nam. }\end{array}$ \\
\hline
\end{tabular}

DOI: https://doi.org/10.34238/tnu-jst.2474

Email: quan.npq@gmail.com 


\section{Introduction}

Located in the Southeast region of Asia, Southeast Asia includes countries which located in the south of China, the east of India, the north of Australia, the west of Papua New Geinea. With an area of about 4.5 million $\mathrm{km}^{2}$, accounting for $10.5 \%$ of Asia and $3 \%$ of the Earth, the region is divided into two groups of countries - Continental countries (including Vietnam, Lao PDR, Cambodia, Thailand, Myanmar, and west Malaysia) and Island countries (including Indonesia, east Malaysia, Singapore, Philippines, Timor Lester and Brunei). The continental countries possesses dense river systems with large water flow including the Mekong River, Salween River, Ayeyarwaddy River, Red River, Chi River, Rajang River..., bringing advantages for hydropower development, which is also the main source of energy for these nations. The total installed small hydropower capacity of Western Asia is $2,340 \mathrm{MW}$ and the estimated potential is $13,642 \mathrm{MW}$, indicating that 17 percent has so far been developed. However, the massive construction of hydroelectricity entails a lot of negative economic, social and ecological consequences for the reservoir area, especially for people who forced to relocate and resettle [1] - [4]. To solve this problem, all countries have their own policies and solutions to create jobs for local people due to hydropower construction, research, learning, and experience exchange among the nations is essential to achieve the most effective solutions for socio-economic stabilization in the resettlement area.

Employment issues have long been an important topic in the world in general and in Southeast Asian countries in particular, and job creation is a basic social policy of the countries for sustainable human development. Southeast Asia has always been considered the most diverse region in terms of ethnicity, language and culture in the world, the region of the "multicultural, multi-ethnic" countries. Along with development progress and development gap reduction efforts, the socio-economic development of ethnic minorities in the country is considered a top strategic issue. Especially in the context of hydropower construction, the most affected group is ethnic minorities since their home, live, and job are changed substantially, all countries promulgate specific policies to create jobs for ethnic minority community to help them quickly integrate with new live and have sustainable livelihood as well as to ensure regional security economic - social stability.

\section{Methodology}

Research methods: By applying empirical research methods and secondary data analysis and synthesis methods, analyzing experience of continental Southeast Asian countries, namely Laos, Myanmar, Thailand and Cambodia, the paper review achievements and consequences of job creation policies for ethnic minority communities affected by electricity constructions in recent years. After that, lessons-learnt were drawn for feasible implementation of job settlement policies for ethnic minority communities in Vietnam.

Regarding approach: the research focus on two main directions: ethnic minority policies, and job settlement policies for ethnic minority communities affected by electricity constructions.

Research period: The study focused mainly on the past 10 years (2010-2019).

Research area: International experience in this topic is relatively diverse. Policies of each country are largely affected by its historical, cultural, and socio-economic background. The study's targeted area is experience of four colonial Southeast Asian countries: Cambodia, Lao PDR, Thailand and Myanmar.

\section{Results and discussion}

\subsection{Cambodia's experience}

Cambodia is located in the Southwestern part of Indochina peninsula with 24 ethnic groups, of which $90 \%$ are Khmer and $10 \%$ are other ethnic groups such as Puon, Krung, Brao, Krao, Pnong, 
Poar, Jarai, Cham, Lao PDR, Thai, Myanmar, Chinese, Malaysia,... For indigenous ethnic minorities, the Cambodian government applies "socio-economic development policies for indigenous peoples" [5] with three key points: (1) Socio-Economic Development, Poverty Alleviation; (2) Complete basic education, improve the quality of human resources; (3) Preserving national culture. However, the main objective of this policy group is to induce a pure Khmer society that has a substantial impact on ethnic minorities in Cambodia [6].

Currently, Cambodia has seven large hydropower plants: Kirirom 1, Lower Sesan 2, Lower Srepok 2, Stung Battambang 1 and Stung Sen, of which Lower Lower Sesan 2 is the largest hydroelectric plant in the country with an investment of US\$ 800 million on Tonlé San river. As a purely agricultural country with over $20 \%$ of agricultural land and about $80 \%$ of the population living in rural areas, hydropower construction have a detrimental impact on Cambodian lives despite of the government's compensation.

It can be seen in table 1 that over the past 10 years, Cambodia has experienced a significant structural shift from agriculture, forestry and fishery to construction, leading to a change in the contribution of agriculture, forestry, and fishing sector into GDP with a decrease of $12 \%$, industry (including construction) increased by $10 \%$. This change is partly contributed by Cambodia's hydropower development policy.

The views of the Cambodian government on resettlement of ethnic minorities due to hydropower construction in general and employment for ethnic minorities due to hydropower construction in particular is the application of settlement and compensation policies through land and credit support. However, the life and environment in Cambodia's hydropower construction and resettlement areas are adversely affected [7].

Table 1. GDP Cambodia Profile

\begin{tabular}{lcc}
\hline \multirow{2}{*}{ Subject } & \multicolumn{2}{c}{ Year } \\
\cline { 2 - 3 } \multicolumn{1}{c}{} & $\mathbf{2 0 1 0}$ & $\mathbf{2 0 1 8}$ \\
\hline GDP (current US\$) (billions) & 11.24 & 24.57 \\
GDP growth (annual \%) & 6.0 & 7.5 \\
Inflation, GDP deflator (annual \%) & 3.1 & 3.1 \\
Agriculture, forestry, and fishing, value added (\% of GDP) & 34 & 22 \\
Industry (including construction), value added (\% of GDP) & 22 & 32 \\
\hline
\end{tabular}

Source: Author compiled from World Bank

Table 2. Employment Cambodia Profile

\begin{tabular}{clcc}
\hline \multirow{2}{*}{ Subject } & Indicator & \multicolumn{2}{c}{ Year } \\
\cline { 3 - 4 } & Employment-to-population ratio (\%) & $\mathbf{2 0 1 2}$ & $\mathbf{2 0 1 6}$ \\
\hline \multirow{3}{*}{ Employment } & 67.0 & 81.2 \\
& Share of agriculture in total employment (\%) & 33.3 & 37.5 \\
& Share of industry in total employment (\%) & 25.2 & 25.8 \\
& Share of services in total employment (\%) & 41.5 & 36.7 \\
& Unemployment rate (\%) & 1.3 & 0.7 \\
\hline
\end{tabular}

Source: Author compiled from International Labour Organization

As shown in table 2, share of agriculture in total employment $(+4.2 \%)$ tends to increase more steadily than share of industry in total employment $(+0.6 \%)$ and share of services in total employment (-4.8\%). Ethnic minorities who rely on agriculture and fisheries in areas affected by hydropower have lost their main livelihood, while vocational training and career change support have not been adopted by the Cambodian government. On the other hand, due to the "assimilation of Khmer" policy, the cultural life of ethnic minorities in Cambodia is 
underestimated, and the infrastructure in resettlement areas was not installed properly, resulting in protests. In many sites, ethnic minorities tried to stay in their homeland, hoping to preserve their cultural identity; those who agreed to reallocate but then have to move out of resettled areas to due to the poor infrastructure.

\subsection{Lao PDR's experience}

Lao PDR located in the center of Southeast Asian mainland, with an area of about 236,800 $\mathrm{km}^{2}$, given its location, it is complicated to determine the ethnic composition. According to the Lao PDR Social Sciences Committee's list in 1985, there are 47 ethnic groups classified into 6 Lao PDR Thay, Mon - Khmer, Mong - Dao, Tibetan - Burmese, Vietnamese - Muong languages, Han. However, due to the complexity in culture, language, name [8].... completely renovated the list of ethnic groups of Lao PDR including 49 ethnic groups, of which the Lao group is the majority group (54.6\%), other ethnic groups are considered as ethnic minorities. With regard to ethnic minorities, the Lao PDR Government focused on developing three main issue groups [9]:

(1) Equality and unity in all ethnic groups, the country takes all measures to gradually develop and improve the socio-economic life of all ethnic groups; (2) Stabilization of residential and cultivated land in midland and highland areas; (3) Relocating and resettling people to favorable areas for agricultural development. Thanks to the geographic and climate advantages, high rainfall during the year, and the system of large tributaries, the Lao PDR Government considers hydropower development as an option to escape the low and underdevelopment [10], as of 2017, in Lao PDR, there are 46 active hydropower plants and 54 plants which were under construction, and as expected, 100 plants will start operation by 2020. Starting in 1993 when the Lao PDR Government allowed foreign investors to participate in the energy sector, the number of hydroelectric plants increased by more than 41 times. In just 7 years, from 2010 to 2017, share of agriculture in total employment (\%) decreased sharply from $71.4 \%$ to $31.3 \%$, partly caused by hydropower development and construction which is a reason of agricultural resources shortage. The results are shown in table 3 . This created negative consequences for the environment, climate change and socio-economic safety and sustainability [11].

Table 3. Employment Lao PDR Profile

\begin{tabular}{llcc}
\hline \multirow{2}{*}{ Subject } & Indicator & \multicolumn{2}{c}{ Year } \\
\cline { 3 - 4 } & & $\mathbf{2 0 1 0}$ & $\mathbf{2 0 1 7}$ \\
\hline \multirow{3}{*}{ Employment } & Employment-to-population ratio (\%) & 77.7 & 36.9 \\
& Share of agriculture in total employment (\%) & 71.4 & 31.3 \\
& Share of industry in total employment (\%) & 8.3 & 14.1 \\
& Share of services in total employment (\%) & 20.2 & 42.2 \\
\hline
\end{tabular}

Source: Author compiled from International Labour Organization

Table 4. GDP Lao PDR Profile

\begin{tabular}{lcc}
\hline \multirow{2}{*}{ Subject } & \multicolumn{2}{c}{ Year } \\
\cline { 2 - 3 } & $\mathbf{2 0 1 0}$ & $\mathbf{2 0 1 8}$ \\
\hline GDP (current US\$) (billions) & 7.13 & 18.13 \\
GDP growth (annual \%) & 8.5 & 6.5 \\
Inflation, GDP deflator (annual \%) & 9.2 & 1.7 \\
Agriculture, forestry, and fishing, value added (\% of GDP) & 23 & 16 \\
Industry (including construction), value added (\% of GDP) & 30 & 32 \\
\hline
\end{tabular}

Source: Author compiled from World Bank 
Table 4 reveals that in recent year, Lao PDR has succeeded in controlling inflation rate, GDP deflator to $1,7 \%$ (reducing $7.5 \%$ in the $2010-2018$ period). As industrial development is given higher priority, the contribution of Agriculture, forestry, and fishing sector into national GPD reduced significantly $(7 \%)$.

The contradiction in the development orientation of Lao PDR, on the one hand, is to stabilize farming, life and resettlement for upland and lowland communes as opposed to focusing on hydropower development, forcing groups to ethnic minorities have to relocate again, changing their living environment and livelihoods, leading to deviations in employment policies for ethnic minorities who are resettled due to hydropower construction in Lao PDR. With more than $80 \%$ of the population live in rural areas, living mainly on agricultural development, hydropower plants occupied agricultural land, ethnic minorities rely mainly on raising their small herds, increasing poverty rates.

With ineffective vocational training and career change support, almost no change in occupational structure, labor rate in agriculture remains high above 70\% [12]. Credit support, infrastructure failed to meet initial targets due to inadequate resources and experience, partly due to the focus to accelerate hydropower development; in many places, ethnic minorities who are not fully supported have returned to their previous residence or continue shifting cultivation.

\subsection{Thailand's experience}

Thailand is a country with a thriving economy in Southeast Asia, the region's second largest economy with an employment rate of $67.28 \%$, unemployment rate of $0.77 \%$, and average monthly income of 14943.73 baht [13] thanks to the successful restructure from a purely agricultural country to a new industrial and service country (tourism and service sectors in Thailand are promoted). Therefore, Thailand's labor allocation in agriculture, industry, and services in 2010-2019 period did not witness substantial changes. The results are shown in table 5-6. With a population of about 69 million, Thailand is the 20th most populous country in the world with $75 \%$ being Thai, $14 \%$ are Chinese, $5 \%$ are Muslims and $1 \%$ are other ethnic groups [14].

Table 5. Employment Thailand Profile

\begin{tabular}{clcc}
\hline \multirow{2}{*}{ Subject } & \multicolumn{2}{c}{ Indicator } & $\mathbf{2}$ Year \\
\cline { 3 - 4 } & & $\mathbf{2 0 1 2}$ & $\mathbf{2 0 1 8}$ \\
\hline \multirow{3}{*}{ Employment } & Employment-to-population ratio (\%) & 67.3 \\
& Share of agriculture in total employment (\%) & 42.1 & 32.1 \\
& Share of industry in total employment (\%) & 19.8 & 22.8 \\
& Share of services in total employment (\%) & 38.0 & 45.1 \\
\hline
\end{tabular}

Source: Author compiled from International Labour Organization

Table 6. GDP Thailand Profile

\begin{tabular}{lcc}
\hline \multirow{2}{*}{ Subject } & \multicolumn{2}{c}{ Year } \\
\cline { 2 - 3 } & $\mathbf{2 0 1 0}$ & $\mathbf{2 0 1 8}$ \\
\hline GDP (current US\$) (billions) & 341.11 & 504.99 \\
GDP growth (annual \%) & 7.5 & 4.1 \\
Inflation, GDP deflator (annual \%) & 4.1 & 1.4 \\
Agriculture, forestry, and fishing, value added (\% of GDP) & 11 & 8 \\
Industry (including construction), value added (\% of GDP) & 40 & 35 \\
\hline
\end{tabular}

Source: Author compiled from World Bank

Starting from a underdeveloped country with an average income of 179,556 baht/household/year and the income of farming households is 105,802 baht/household/year [15] with little added value of goods compared with the input investment, the value of agricultural 
products is low and unstable, low level of cultivation and technical expertise, family planning issues and large population,... and many other economic issues. The economic and social situation have prompted the Government of Thailand to introduce special solutions to change the situation and restructure the industry to bring Thailand to develop as it is today. The solutions are divided into 3 main phases (1) Restructuring stage - Patiwatn: Restoring destroyed natural environment, increasing the participation of ethnic minorities and mobilizing participation of sectors and industries; (2) Period of reform - Apiwatn: Building organizations to enhance trade, develop tourism with orientation to industry restructure, trade promotion, access to external commodity markets, product branding to enhance the value of products, to improve new technologies and to develop risk management channels; (3) Period of moral reform Thammapiwatn: Using high technology in production, encouraging young workers to return home by scholarship funds, applying the "reed" policy to take advantage of maximizing development resources.

As for hydropower construction, Thailand is the less favorable and the second most affected country in the region. Because Thailand located in the tributary and the lower basin of the river, Thailand had to sacrifice a lot of agricultural land as well as access to livelihoods from agriculture and fisheries to hydropower construction. With increasing hydropower development of upstream countries to export energy to Lao PDR and China, many hydropower plants in Thailand lose electricity production capacity; some hydroelectricity has turned into lakes, dams to regulate water for other hydroelectricity or to serve as agricultural irrigation.

Despite the unfavorable environmental conditions, reasonable policy making in each period ensured high employment rate and restructure of ethnic minorities due to Thailand's hydropower construction. The support for vocational training and job restructuring were applied widely, ethnic minorities can develop not only agriculture but also develop high-tech agriculture to bring higher values. Ethnic minorities have been trained and instructed to take advantage of cultural and life factors to develop tourism and service industries.

\subsection{Myanmar's experience}

Myanmar is the largest country in Southeast Asia with a population of about 51 million people and an area of about $676,578 \mathrm{~km}^{2}$ [16]. It is also the country with the most complex ethnic composition in the region with 8 main ethnic groups and more than 87 small ethnic groups [17] with GDP growth annual rate $6.2 \%$ and tended to level off, GDP deflator to 1,3\% (reducing $7.5 \%$ in the 2010-2018 period). The results are shown in table 7.

Table 7. GPD Myanmar Profile

\begin{tabular}{lcc}
\hline \multirow{2}{*}{ Subject } & \multicolumn{2}{c}{ Year } \\
\cline { 2 - 3 } & $\mathbf{2 0 1 0}$ & $\mathbf{2 0 1 8}$ \\
\hline GDP (current US\$) (billions) & 49.54 & 71.21 \\
GDP growth (annual \%) & 9.6 & 6.2 \\
Inflation, GDP deflator (annual \%) & 7.0 & 8.3 \\
Agriculture, forestry, and fishing, value added (\% of GDP) & 37 & 25 \\
Industry (including construction), value added (\% of GDP) & 26 & 32 \\
\hline
\end{tabular}

Source: Author compiled from World Bank

Deeply affected by British colonial rule, ethnic issues in Myanmar in the previous period were deeply divided, conflicts occurred between ethnic groups as well as within the groups. By the time the Myanmar Government came to power, the democratic process was intensified, the reforms were divided into four main stages: (1) Political reform, all ethnic groups were developed equally and neutralizing previous aggressions, enhance exchanges between groups; (2) 
Economic and social reforms to improve the quality of life of all ethnic groups; (3) Public administration reform with the aim of cleaning the apparatus, combating corruption, considering using the private economic development as a driving force for reform (4) Reforming mechanisms, building a framework of law, investment support to promote economic development orientation.

Hydroelectric plants in Myanmar contribute 55\% of the country's electricity output [18] but according to the Myanmar electricity development plan in 2018, nearly 60\% of rural households could not access to electricity. This leaves Myanmar in a state of severe energy shortage. With a clear policy line, the Myanmar Government has put stabilization and development as their top priority, so many hydropower projects in Myanmar have been "suspended" indefinitely.

On the other hand, due to the long ethnic separation period, Myanmar's infrastructure is also considered to be the worst in the region, so the infrastructure support of job creation policies in Myanmar is not developed. In addition, Myanmar's labor skills and labor attitude are not highly appreciated, the labor force is mainly an immigrant labor from surrounding countries. Creating jobs for ethnic minorities resettled by hydroelectric construction in Myanmar is still a big problem revolving around the developmental axis of the country.

\section{Conclusion}

Through studies and assessments on the experience of some Southeast Asian countries, it can be seen that this area has a great potential for hydroelectricity. Hydropower energy not only serves the needs of domestic economic development but also helps bring about great economic benefits thanks to energy exports. However, this is also a region with unique national identities, which makes each country has its own strategies for development and management of ethnic issues in general and employment issues for the ethnic minorities relocated due to hydropower construction in particular. There are two common characteristics of these countries in job creation for ethnic minorities who are resettled due to hydropower construction:

(1) Lack of balance in policies for ethnic minorities, in other words, policies for ethnic minorities are always dominated, inferior to other policies. Only in Myanmar, after a long time of ethnic division, would this benefit be on par;

(2) Lack of long-term vision for policies, employment policies are promulgated without the support of other component policies such as credit support, land support, infrastructure development, vocational training assistance and job transition. Thailand alone is a quite successful country when it has applied nearly all of the component supports to solve employment problems and develop regional economy.

Based on the experiences from some Southeast Asian countries, the author proposes a number of solutions to complete employment resettlement policies for ethnic minorities due to hydropower construction in Vietnam as follows:

(1) It is necessary to have separate policy groups depending on the actual situation, the ethnicity of the resettlement area to resolve cultural and social conflicts, including: cultural life, customs of resettled ethnic minority people.

(2) It is necessary to have a clearly oriented strategy in vocational training, career change and avoid stereotypical applications from a province to others (promote internal development of the ethnic minorities in the area to develop traditional occupations) along with communication support, branding support to enhance the value of products made by the people.

The issue of resettlement and sustainable resettlement is difficult to solve harmoniously in regions and countries, especially countries with a large cross-border between ethnic groups. How to solve well the issues of livelihood, people and job creation in resettlement areas will be the key to create a stable and sustainable development situation in the resettlement areas. 


\section{REFERENCES}

[1] Y. Zhang, D. He, Y. Lu, Y. Feng and J. Reznick, "The influence of large dams building on resettlement in the Upper Mekong River," Journal of Geographical Sciences, vol. 23, pp. 947-957, 2013.

[2] M. Nakayama and R. Fujikura, "The long-term impacts of resettlement programmes resulting from dam construction projects in Indonesia, Japan, Laos, Sri Lanka and Turkey: a comparison of land-forland and cash compensation schemes," International Journal of Water Resources Development, vol. 29, pp. 4-13, 2013.

[3] N. Dao, "Dam Development in Vietnam: The Evolution of Dam-Induced Resettlement Policy," Water Alternatives, vol. 3, pp. 324-340, 2010.

[4] United Nations Industrial Development Organization (UNIDO), "World Small Hydropower Development Report 2016," Tech. Report, 2016.

[5] L. B. Nam, Some basic and urgent issues about ethnic minorities in China and Southeast, Hanoi: Vietnam National University-Hanoi, 2019.

[6] National Assembly of Cambodia 1st, Khmer Citizenship Law. Phnom Penh, Cambodia: National Assembly, 1996.

[7] Rivers Coalition in Cambodia (RCC), "Rivers Coalition in Cambodia repoter 2015-2018," Tech. Report, 2015-2018.

[8] Lao Institute of Ethnology, List of ethnic groups in Laos. Vientiane, Laos: Institute of Ethnology, 1992.

[9] Lao PDR National Assembly, Constitution of Lao PDR 1991-2003. Vientiane, Laos: National Assembly, 1991-2003.

[10] Lowy Research Institute - Australia, “Annual report 2016- 2018,” Tech. Report, 2016-2018.

[11] Mekong River Commission, "State of the Basin Report 2010 MRC," Tech. Report, 2010

[12] Lao Ministry of Labor and Social Welfare, “Annual report 2015,” Tech. Report, 2015

[13] International Labor Organization (ILO), Thai statistics 2018. Geneva, Switzerland: Office of Headquarters Operations, 2018

[14] United Nations (UN), "Statistical report of Southeast Asia region 2018," Tech. Report, 2018.

[15] International Labor Organization (ILO), Thai statistics 2005. Geneva, Switzerland: Office of Headquarters Operations, 2005

[16] Asian Development Bank (ADB), $A D B$ and Myanmar: Fact Sheet. Mandaluyong, Metro Manila, Philippines: Office of Headquarters Operations, 2013

[17] Government Myanmar, List of groups of people. Naypyidaw, Myanmar: Government, 2001.

[18] International Energy Agency (IEA), “Annual report 2016,” Tech. Report, 2016. 